\title{
MORPHOLOGIC STUDY OF LYMPHATIC TISSUES (XIII) LIGHT AND ELECTRON MICROSCOPE OBSERVATIONS ON THE BURSA OF FABRICIUS OF THE CHICK AND COTURNIX EMBRYOS WITH SPECIAL REFERENCE TO LYMPHOCYTOPOIESIS
}

\author{
TOHRU ARAMAKI \\ Department of Pathology, School of Medicine, \\ Keio University, Tokyo, Japan
}

(Received for publication April 30, 1968)

\section{INTRODUCTION}

Study of the bursa of Fabricius of fowls has been one of current topics in the field of development of central lymphoid tissues associated with immunological functions. It was elucidated that the organ played a role in produciton of humoral antibodies. ${ }^{10,11,12,37,40}$ Surgical bursectomy within one week after hatching was shown to almost completely inhibit production of various antibodies. ${ }^{7}$ 11,14,19,26,30,34,35,39,43 Hormonal bursectomy (by testosterone and its derivatives) $2,6,11,16,24,26,31,35,41,43$ at stages prior to the 12th day of incubation of the chick embrya also showed complete suppression of lymph follicle formation associated with inhibition of antibody production after hatching. The selective suppression of different types of immune responses by thymectomy or bursectomy led to the formulation of the concept of a dissociation of immune responses by Szenberg and Warner ${ }^{40}$ and Cooper et al. ${ }^{11}$ Their studies showed that the bursa controled the development of cells of the plasmacytic series which were concerned in immune reactions mediated by humoral antibody, and that the thymus was primarily concerned with the development of cells of the lymphocytic series which mediated direct cellular response to antigenic challenge. Formerly Jolly and his contemporaries ${ }^{20}$ and recently Ackerman ${ }^{1}$ studied extensively the development of the bursa of Fabricius in the chick embryo by light microscopy. In 1966 Moore and his colleague ${ }^{25}$ published a report on experimental studies of the development of the bursa using several unique methods (chromosome marker, 
and parabiosis techniques). Jolly and Moore et al. concluded, on their different technical bases, that the lymphocytic transformation in the epithelial bud took place by immigration of lymphocytic cells derived from undifferentiated mesenchymal cells in the tunica propria or from other unknown sites including thymus. In contrast, Ackerman, supplemented by electron microscopic observations, ${ }^{3}$ concluded that the lymphocytic cells of the lymphoepithelial organ of birds arose from undifferentiated endodermal epithelial cells and from mesenchymal cells (see Fig. 3).

The author attempted to determine the fine structure of the cellular components and cell-to-cell relationships in the developing follicles of bursa of Fabricius of chick and Coturnix embryos. In the observations of lymphocytopoiesis in the epithelial bud, transistional forms between epithelial cells and lymphoblasts were characterized with special precaution, which was of utmost importance when development of the cell line was pursued.

\section{MATERIALS AND METHODS}

The bursa of Fabricius was taken off from white Leghorn chick embroys between 13th and 21st day of incubation and from Coturnix coturnix japonica (a species of quail) embryos of 15th day of incubation (one day prior to hatching), cut into small pieces, and fixed for two hours in ice-cold $1 \%$ osmium tetroxide, buffered to $\mathrm{pH} 7.2$ with phosphate. Tissues were embedded in Epon 812..3 Thin sections were cut with glass knives on Porter-Blum and LKB microtomes, mounted on grids of 200 and 127 microns in hole diameter and stained for 3 minutes with lead alone, modified from Reynolds, ${ }^{32,33}$ or doubly stained with uranyl acetate followed by lead. Sections of 0.5 to 1 micron were also cut from the Epon blocks, affixed to glass slides by heating, stained with alkaline methylene blue and examined by light microscope, prior to electron microscopic observations.

\section{OBSERVATIONS}

\section{A) LIGHT MICROSCOPY}

Light microscopic findings are briefly described here as Jolly ${ }^{20}$ and Ackerman et al. ${ }^{1}$ have dealed in detail with the development of lymph follicle of the bursa.

1) 13th day of incubation of chick embryo (Figs. 4 and 5)

The lymphocytopoiesis in the epithelial bud began at this stage. The epithelial bud arose from the surface endodermal epithelium and recognized as 
a protrusion of a hemispherical convex structure into the tunica propria. Basophilic pyronin-positive oval or round cells measuring 6 to 8 microns began to appear in a very small number in the bud consisting of purely epithelial cells. The basophilic cells were similar to lymphoblasts in respect to morphological characteristics. Subjacent to the bud in the tunica propria the blastic cells were sometimes identified by light microscopy. The basement membrane was only rarely observed. In the tunica propria unidentifiable mesenchymal cells, granulocytes (eosinophilic peroxydase-negative granulocytes), fibroblastic cells and capilllaries were scattered at random.

2) 15th day of incubation of chick embryo (Fig. 6)

The epithelial buds became far more numerous and enlarged. The buds were recognized as developing lymph follicles, where basophilic cells were observed much more frequently. The epithelial cells were more elongated and flattened due to the presence of free cells, and began to form a reticular strueture. Subjacent to the bud there were accumulations of unidentifiable mesenchymal cells, lymphoblasts and lymphocytes. This cell group surrounded the follicle as a cell sheet and was easily recognized as the future outer or cortical zone. The basement membrane was often obscured in the polar region of the follicle, possibly due to the disruption of the membrane and passage of the cells to the tunica propria, which will be later elucidated by electron microscopy.

3) 16th and 17th day of incubation of the chick embryo (Fig. 7)

In the epithelial bud distinct pyroninophilic cells were observed scattered as free cells. The subjacent area to the bud showed disappearance of large pyroninophilic cells. Along with small number of lymphocytic cells, elongated mesenchymal cells were adjoined with basal layer of the bud, where the basement membrane was hardly seen.

4) 18th, 19th and 20th day of incubation of the chick embryo and 15th day of incubation of Coturnix embryo (Figs. 8, 9, 11 and 12)

At these stages the basic follicle structure seemed to be completed. The inner (or medullary) and the outer (or cortical) zones could be distinctly differentiated, although the basement membrane was hardly visible by usual staining methods. The follicles increased in number and size. In the inner zone, the lymphoid cells, along with mitotic figures, became more numerous. In the outer zone, too, there were distinct two or three-cell layer of lymphocytic series. Cells covering the surface of the inner zone assumed a more columnar shape. Lymphocytic series consisted mainly of large lymphoblastic cells measuring 7 to 10 microns in diameter, showed an intense basophilic pyroninophilic cytoplasm (Fig. 12) and rather homogeneous chromatin in the nucleus and single or double nucleoli. Besides, large and medium-sized lymphocytes were seen in a small 
number. The outer zone consisted of a network of reticular cells the interspace of which lymphocytic series filled. Mesenchymal cells also contributed to these cell accumulations. In the tunica propria eosinophilic granulocytes were also seen in a small number. Even with Jones' silver impregnation the basement membrane of the polar region were scarcely revealed by light microscopy. The findings of Coturnix embryos at 15th day of incubation largely corresponded to those of chick embryos at 20th to 21 st day of incubation.

5) 70th day after hatching of the chick (Fig. 14)

The tunica propria was largely occupied by numerous large lymphoid follicles closely adjoining with each other, between which only a thin strand of connective tissue was inserted. At this stage cells covering the surface of the inner zone assumed a prominent cloumnar shape, and possessed a continuous basement membrane. With Carnoy's fixation and H-E staining and also with silver impregnation the basement membrane was well demonstrated.

\section{B) ELECTRON MICROSCOPY}

1) 13th day of incubation of the chick embryo (Figs.27 and 28)

The epithelial bud was recognized as a protrusion from the surface epithelium into the tunica propria. It consisted of undifferentiated epithelial cells, basophilic lymphoblasts and various intermediate forms between the two. The undifferentiated epithelial cells (cells of Nos. 9, 11, 22, etc.) possessed a round or oval nucleus with little chromatin condensation and single or double desitinct moderately dense nucleoli. The cytoplasm was partly elongated and formed a cellular reticulum, although not well developed at this stage. The cells of basal areas (cells of Nos. $6,8,9,14,19,22,31,32$, etc.) and adjacent to the surface epithelium (cells of Nos. 1, 2, 3, 5, 33, 35, 40, 41, 42, 43, 46, 47, 48, and 49) extended their cytoplasmic processes and connected each other with typical desmosomes. Mitochondria were oval or rod-shaped and medium in size. Rough and smooth elements of endoplasmic reticulum were few in number. Number of free ribosomes varied greatiy from one cell to another. Surface and undifferentiated epithelial cells could not be distinguished in respect to their organelles. A few cells characterized by the presence of abundant free ribosomes and large mitochondria were seen in the epithelial bud (cells of Nos. 10, and 23 of Fig. 27). A delicate, moderately dense basement membrane measuring about 50 to 70 milimicrons in thickness was continuous with that of the surface epithelium. Disruption of the membrane was frequently observed at the polar region of the bud, where mesenchymal and/or lymphoblastic cells were in close contact with the basal epithelial cells (arrow in Fig. 27 and Fig. 16).

In order to characterize each cell in the bud shown in Fig. 12, the present 


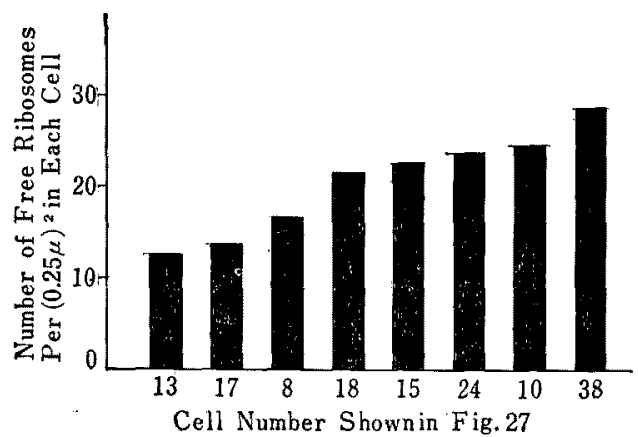

Fig. 1. Comparison of number of free ribosomes of eight cells of one epithelial bud of bursa of $13 \mathrm{th}$ day of incubation of a chick embryo. See page 152 for further explanation of Figs. 1 and 2 .

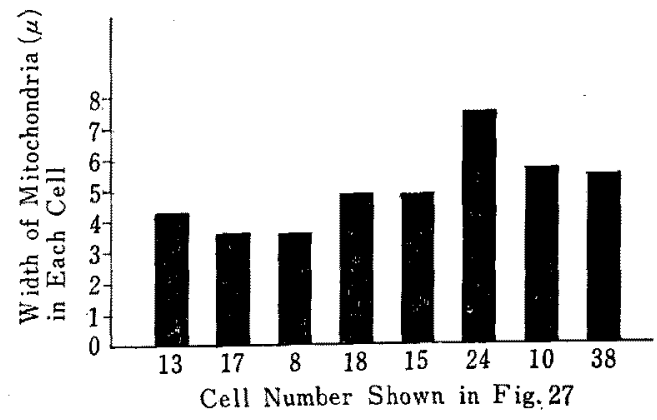

Fig. 2. Comparison of thickness of mitochondria of eight cells in the same bud as of Fig. 1.

author analized number of free ribosomes per 0.25 micron squares and average width of mitochondria in each of representative eight cells in the bud (cells of Nos. $8,10,13,15,17,18,24,38$ of Figs. 27 and 28 ). In each one cell the number of free ribosomes in ten randomly selected 0.25 micron squares were counted and the averages taken. Widths of ten mitochondria in the eight selected cells were measured and the averages taken (Figs. 1 and 2). Figs. 1 and 2 show that ribosome-rich cells tend to have large thick mitochondria. In the epithelial bud of Figs. 27 and 28 obvious lymphoblastic cells with abundant free ribosomes and thick mitochondria were seen (cells of Nos. 10, and 23 of Figs. 27 and 28). There were some cells which possessed moderate number of free ribosomes and moderate width of mitochondria (cells of Nos. 15, 18, 31, etc.). At the other extreme, typical epithelial cells with scant ribosomes and thin mitochondria (cells of 8,13 and 17) were identified. On the other hand there were no protoplasmic bridges or desmosomes between lymphocytic cells and epithelial cells and between intermediate forms and epithelial cells. By this analysis it may be concluded that, in the lymphoepithelial nodule there were transitional forms between undifferentiated epithelial cells and lymphoblasts. In the tunica propria there was an accumulation consisting of lymphoblastic cells and intermedatie forms close to the bud near the disrupted area of the basement membrane (cells of Nos. 4, 7, 24, 26, 38 and 39). In the area of the basement membrane a close contact between one lymphoblast and one epithelial cell (arrow in Fig. 16) was observed. There were also mesenchymal cells which appeared undifferentiated and fibroblastic cells, closely associated with the lymphoblasts, but not connected 
with desmosomes or tight junctions (Fig. 16).

2) 15th day of incubation of the chick embryo (Fig. 30)

As Fig. 30, a traced figure of an electron micrograph of one developing lymph follicle showed, the follicle was enlarged, and lymphocytic cells were increased in number both in the bud and the subjacent tunica propria. Not only lymphoblastic cells but also large and medium-sized lymphocytes measuring 7.0 to $\mathbf{1 0 . 0}$ microns in diameter appeared. The epithelial cells in the central portion of the inner (or medullary) zone extended their cytoplasm to form a network or cellular reticulum, connecting each other with desmosomes. The disruption of the basement membrane in the polar region (arrows in Fig. 29) became more prominent and evident passages of undifferentiated epithelial cells as a group through the crevices of the basement membrane to the outer zone in the tunica propria (Fig.18). These cells were connected with epithelial cells of the inner zone by desmosomes. Close to these migrating cells there were lymphocytic series present in the propria. Large and medium-sized lymphocytes (Fig. 19) have rounded contour without cytoplasmic processes. Cells with single nucleoli were seen but less prominent than in lymphoblasts. Perinuclear condensation of chromatin became more marked. Free ribosomes were not decreased in number. Nucleo-cytoplasmic ratios were not so large as in mediumsized lymphocytes in other lymphoid organs. Polyribosomes were abundant in the cytoplasm, reflecting marked pyroninophilia. Close contact between epithelial cells of the inner zone and mesenchymal cells was the characteristic finding at this stage (Fig. 20). Desmosomes between epithelial cells were, in general, shorter and fewer than those seen in the thymic epithelial reticular cells. In the cytoplasm thick bundles of tonofilaments were seen in small number and usually situated along the cell border. Cells filled with spherical granules recognized as eosinophilic granulocytes were encountered in a numerous number at this stage (Fig. 22).

3) 18th and 19th day of the chick and 15th day of incubation of Coturnix embryos (Figs. 29 and 31)

The development of the lymph follicle appeared to have been accomplisehd at this stage. The inner and outer zones were well distinguished. The outer zone consisted of two or three layers of lymphocytic cells in a loose reticular cell network. The two zones were almost completely separated by a delicate basement membrane, the disruption of which was only rarely found. The inner zone was filled with numerous large and medium-sized lymphocytes. The reticular network was formed by thin cytoplasmic processes of epithelial reticular cells connecting each other with short desmosomes (Fig. 21). They usually had fine tonofilaments, small amount of free ribosomes and scant rough endo- 
plasmic reticulum. No blood vessels were found in the inner zone through all stages of incubation. They were frequently observed in the outer zone, usually closely associated with the basement membrane (Fig. 21). The epithelial reticular cells close to the basement membrane showed scattered dense plaque at their cell border (Fig. 21). In one micrograph (Fig. 24) the passage of a lymphocyte either from the inner to the outer zone or vice virsa through the disrupted basement membrane was clearly demonstrated. The nucleus of the lymphocyte was dumbbell-shaped and narrowed at a crevice $\bar{e}$ of the basement membrane. The RNP particles were far more concentrated on the side of the outer zone (see arrow of Fig. 24).

Infrequently reticular cells connected by desmosomes were seen in the outer zone (Fig. 26), which indicated the presence of epithelial cells in the outer zone. No distinct border between the outer zone and the tunica propria could be delineated. In the surroundings there were fibroblastic cells, undifferentiated mesenchymal cells and granulocytes. Collagen fibrils were seen scattered in the intercellular space. The granulocytes (Fig.23), observed as eosinophilic granulocytes by light microscopy, possessed a dozen of spherical or oval dense homogeneous granules measuring from 100 to $800 \mathrm{~m} \mu$ in diameter at one side of the nucleus. A small number of vacuoles containing dense coarse granular grains were also present. Transitional forms between the two types of granules were sometimes encountered. Rough endoplasmic reticulum and Golgi complex were well developed.

For the analysis of lymphocytic cells of the bursal follicles at 15th day of incubation of Coturnix embryo (Figs. 15, 25, 30 and 31) which corresponded to 20 th to 21 st day if incubation of the chick, a random selection of profiles of about

Table 1

Cytoplasmic diameters of lymphocytic cells of the bursal follicles of 15th day of incubation

(Coturnix coturnix japonica)

\begin{tabular}{ccccc}
\hline $\begin{array}{c}\text { Diameters } \\
\text { (Micron) }\end{array}$ & Number of cells & Per cent & Number of cells & Per cent \\
\hline-4.0 & & & 1 & 2.6 \\
$4.0-6.0$ & 13 & 15.9 & 12 & 30.8 \\
$6.0-8.0$ & 42 & 51.2 & 23 & 58.8 \\
$8.0-10.0$ & 24 & 29.3 & 2 & 5.2 \\
$10.0-$ & 3 & 3.6 & 1 & 2.6 \\
Total & 82 & 100.0 & 39 & 100.0 \\
\hline
\end{tabular}


80 cells in the inner zone and about 40 cells in the outer zone from the lowmagnified (3,000 to 4,000 times) micrographs was made and their total cell diameters, along the long axis and the axis perpendicular to it, were measured. The averages of the two diameters in each instance were taken, and defined as cytoplasmic diameters. In this measurement profiles of tangential sections were excluded as far as possible (Table 1). Cytoplasmic diameters in the inner zone showed a peak at the 6.0 to 7.9 micron group (51.2 per cent) and the vast majority were between 6.0 and 9.9 microns ( 80.5 per cent). In the outer zone the diameters showed a peak at the 6.0 to 7.9 micron group and 89.6 per cent were between 4.0 to 8.9 microns. The analysis indicates that the lymphocytic cells composing both zones of the bursal follicles were larger than those of the thymus at the corresponding stage of the chick (compare Figs. 8 and 10 and see reference 27 and 36) and that those of the inner zone were larger than those of the outer zone.

No plasmacytic cells and transitional forms from lymphocytic cells were observed in the follicle and the tunica propria at the stages examined.

\section{DISCUSSION}

The development of the bursa of Fabricius was studied extensively by $J_{o l l y}{ }^{20}$ and his contemporaries between 1850 and 1920 . With recognition of the functional role of this organ, Ackerman and his associates ${ }^{1,2,3}$ confirmed the findings of Jolly and other investigators and developed their concept associated with immunological data and histochemical observations. ${ }^{2}$

The author confirmed their findings in several respects and added to further new morphological data by electron microscopy: from the findings described in OBSERVATIONS the development of the bursal follicle is summarized as follows.

During the formation of follicles of bursa three developmental stages are distinguishable: 1) stage of epithelial bud 2) developing stage and 3) maturation stage.

1) Stage of epithelial bud (12th and 13th day of incubation of the chick embryo)

The bud is at first recognized as a small nodular thickening of the surface epithelium of the bursa protruding into the tunica propria. This epithelial bud is filled with undifferentiated epithelial cells which are characterized by the presence of homogeneous oval nucleus with single or double nucleoli, thin mitochondria, scant free ribosomes and poorly developed endoplasmic reticulum, and typical protoplasmic junctions or desmosomes. The basal surface of the bud 
is covered by distinct basement membrane continuous with that of the surface epithelium. The observations on the later stages of the bursa show that the epithelial bud is the future inner (or medullary) zone of the bursal lymph follicle.

2) Developing stage (13th to 18th days of incubation of the chick embryos)

This is a most active stage characterized by marked increase in size and by the distinct changes of the structure of bursal follicle. The prominent changes seen at this stage are A) the appearance and proliferation of lymphocytic cells in both epithelial bud and subjacent tunica propria; undifferentiated epithelial cells are partially transformed into basophilic pyroninophilic ribosome-rich lymphoblastic cells which are further differentiated into lymphocytic series. In tunica propria, too, lymphocytic cells appear along with those in the epithelial bud. Lymphocytic cells continue to increase in number in both epithelial bud and surrounding tunica propria, B) the formation of epithelial reticulum in the bud; the epithelial cells are elongated and form a cellular reticulum of the bud which is not contributed to by mesenchymal cells and blood vessels. C) The disruption of the basemnet membrane; it begins along wtih the appearance of lymphocytic cells in the bud. It becomes most prominent at 15th day of incubation of the chick embryo and the membrane is reconstructed gradually for about 5 days thereafter towards the 20th day of incubation. D) The invasion of epithelial cells through the crevices of the basement membrane into the tunica propria; clusters of epithelial cells still connected with those of the bud protrude into the tunica propria through the basement membrane to make a close contact with mesenchymal cells and lymphocytic cells in the tunica propria. The degree of the protrusion parallels to that of the disruption of the basement memberane.

3) Maturation stage (18th to 21st days of incubation of the chick embryos and 15th day of incubation of Coturnix embryo)

At this stage the formation of the bursal follicle is accomplished. The inner (or medullary) and outer (or cortical) zones are clearly distinguished. The former is enveloped by a thin layer of epithelial reticular cells and filled with numerous lymphocytic cells. Slender reticular cells are recognizable in the interspaces among lymphocytic cells. In the outside of the epithelial sheath of the inner zone, a distinct basement membrane is present. At this stage the disruption of the membrane is only rarely observed. Infrequent small discontinuities are encountered in both epithelial sheath and basement membrane. Lymphocytic cells pass freely through these gaps. The invasion of epithelial cells into the outer zone is not seen at this stage. Occasionally small clusters of cpithelial reticular cells, characterized by the presence of desmosomes, are seen 
in the outer zone. This seems to indicate that the epithelial cells become to be dissociated from the inner zone during the reconstruction of the basement membrane and to be fixed as part of the reticulum of the outer zone. The blood vessels never invade the inner zone, but their close apposition to the basement memberane of the inner zone border is characteristic.

\section{Origin, differentiation and migration of bursal lymphocytic cells}

There is no doubt that the bursa of Fabricius is a specialized lymphoepithelial organ peculiar to birds which is composed of epithelial reticulum and lymphocytic cells ${ }^{1,3,20}$ as seen in the thymus.,9,21 But there are everlasting hot arguments in respect to the origin of lymphocytic cells in both organs; it is not yet determined whether they are derived from epithelial cells or from other mesenchymal cells. As far as the thymus is concerned, some reports upon confirmative evidence of epithelial origin of lymphocytic series have been made, ${ }^{8,4,17}$, 28 , but there has been no actual proof that lymphoblastic cells of the bursal follicle are of epithelial origin.

In order to solve this problem by morphological methods, firstly a critical stage where lymphocytic cells begin to appear in the epithelial bud has to be strictly selected. Secondly it is essential to characterize and classify each cell in one bud. Distinct opithelial cells and lymphoblastic cells are easy to be identified but intermediate forms between the two are difficult to be classified and tend to be named arbitrarily.

Usually an actual proof that one specific cell is transformed into the other is difficult to be obtained as far as the present morphological observations are concerned in studies dealing with the development of one cell line. In this connection, in order to give a more conclusive evidence for the transformation from one cell to the other on a morphological basis, it is most important to show clearly the presence of various intermediate forms to fill the gaps between the two specific cells concerned.

The present study deals especially with this "transformation" problem. The characterization of all cells in a certain developing follicle at a submicroscopic level is one attempt to fill the gaps between undifferentiated epithelial cells and lymphocytic series. The selection of number of free ribosomes and width of mitochondria as indicators of the characterization of specific cells may be arbitrary, but other specific indicator for cell characterization are lacking in lymphocytic cells; in other words they can be characterized as simple or unspecified cells and only exceptions are abundant ribosomes and thick mitochondria. As Figs. 1 and 2 show, it is reasonable to conclude that there are actually intermediate forms between the two cell types. It is possible that the undiffer- 
entiated epithelial cells are transformed into lymphoblastic cells or vice virsa. From observations of development of bursal follicles, it is difficult to believe that lymphoblastic cells are transformed into epithelial cells, because no lymphoblastic cells are seen in the epithelial bud at earlier stages (before 12th day of incubation of chick embryos). It thus follows that epithelial cells are transformed into lymphoblastic cells.

On the other hand it is natural to believe that certain adjoining cells are of the same origin if there is a desmosome between them, and that the presence of the desmosome between two different types of cells indicates a high possibility of the transformation from one type to another. ${ }^{13}$ Although there are some exceptional cases in the thymus ${ }^{8,17}$ and experimental thymic tumors ${ }^{4,24}$ which show the presence of a desmosome between a thymocyte and an epithelial cell, no desmosomes were found between epithelial and lymphoblastic cells including their intermediate forms in the bursal follicles. It may be reasonable to assume that any protoplasmic bridges or contacts will disappear prior to the transformation of one of the two cells concerned ${ }^{13}$ and that the presence of the structures between two different types of cells are unusual.

The passage of undifferentiated mesenchymal cells or lymphoblastic cells from the tunica propria through the basement membrane, followed by transformation into more mature lymphocytic series and by proliferation is one of possibilities (migration theory), which is beyond my present scope, but does not contradict my findings. Jolly ${ }^{20}$ studied, in several fowls, the histogenesis of the lymph follicle of the bursa. By Zenker's formalin fixation which enabled him to differentiate lymphoblastic cells from epithelial cells, he observed the developing follicle at critical stages in respect to lymphocytopoiesis (12th to 14th days of incubation in case of the chick) and described that numerous basophilic amoeboid cells were accumulated in the subjacent area of the epithelial bud. These cells were seen to penetrate into the bud, some of them were still in the tunica propria and others reached the bud and in progress of penetration. In other experiments he showed the capacity of the movements of lymphocytic cells of the dissociated bursal lymph follicle suspended in the serum but he did not get the true evidence of the amoeboid cells in vivo penetrating the bud by light microscopy. He concluded from these observations that the lymphocytic series were derived from basophilic wandering cells in the tunica propria which were possibly of mesenchymal origin. He did not mention the intermediate forms between lymphoblastic cells and epithelial cells in the bud at this stage and denied the epithelial origin of lymphocytic cells. His conclusion is not convincing in that his observations in respect to "migration" from the tunica propria to the bud are purely static and not dynamic. It can not 
be determined from his observations in which direction the basophilic cells migrate; from the tunica propria to the bud or vice virsa. Thus his findings can be interpreted in two ways: one is his interpretation that lymphocytic cells migrate from the tunica propria into the bud, proliferate and are differentiated in situ, and another is that wandering cells transformed from epithelial cells in the bud migrate to the tunica propria to colonize the subjacent area of the bud which will become later the outer zone. My observations do not rule out both interpretations.

Moore et al. ${ }^{25}$ made an analysis of the origin of lymphocytic cells in the developing bursa of Fabricius using a chromosome marker technique in combination with various experimental procedures including parabiosis of embryos of similar major histocompatibility type, twin embryo studies, transplantation of bursal rudiments to the chorioallantois. He concluded that the majority of bursal lymphocytes were derived from blood-borne projenitor cells which entered the bursal primordium during embryogenesis, although the structure and sites of origin of the progenitor cells were not determined. His study did not rule out that lymphocytic series were of dual origin but showed an actual proof that blood-borne undifferentiated cells could enter the bursal primordium.

Ackerman et al., in their electron microscopic observations, ${ }^{3}$ characterized lymphoblastic cells as "tending to be slightly larger than the undifferentiated basal (epithelial) cell and rounded in contour with deeply dense cytoplasm and scant rough endoplasmic reticulum, with rounded slightly more dense nuclei than those of the undifferentiated epithelial cell." They concluded that the epithelial bud consisted of purely epithelial cells which underwent transformation directly into lymphoblasts and lymphocytes and that lymphocytic cells of the outer zone (or cortical portion) had two sources from mesenchymal cells in the tunica propria and from epithelial cells or lymphoblasts which moved from the inner

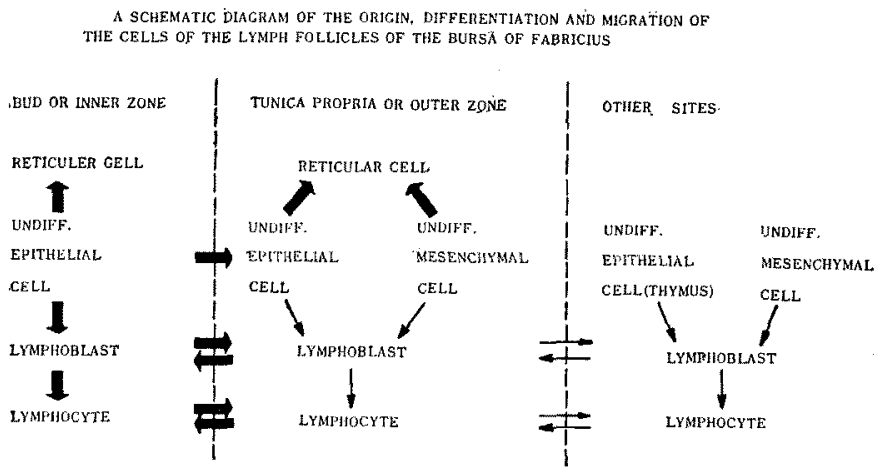

Fig. 3. See page 152 for explanation 
to the outer zone through the basement membrane. They considered without convincing findings that lymphoblasts and/or undifferentiated epithelial cells occasionally might pass through the basement membrane from the medulla into the cortex of the developing nodule and that there were also transistional forms between mesenchymal cells and lymphoblasts in the outer zone.

While Ackerman's light microscopic observations ${ }^{1}$ showed that lymphoblastic celis were rarely seen outside of the epithelial bud during 13th and 15th day of incubation of the chick embryos, Jolly ${ }^{20}$ and the author clearly demonstrated typical lymphoblastic cells along the border of the bud (see Figs. 27 and 28). Thus the dual origin of lymphocytic series not only in the outer zone but also in the inner zone of the bursa is more plausible. The findings and conclusions of the present author and other investigators $1,3,18,20,25,42$ concerning origin, differentiation and migration of the bursal lymphocytic cells, are summarized in Fig. 3.

\section{Other roles of epithelial cells in the bursal follicles}

Undifferentiatd epithelial cells are observed, in sevevral instances, passing through the basement membrane of the bud in either direction. The disruption of the basement membrane is a constant finding at stages from 13th to 15th day of incubation of the chick embryos. The stages appear to be those at which epithelial cells in the bud can make a free contact with the tunica propria and mesenchymal cells which indicates an interaction between the two cell systems. More mature, smaller lymphocytic cells in the tunica propria at the stages may be derived from the bud or borne from the unknown site through the peripheral circulation (i.g. from the thymus and other lymphoid systems).

The phenomenon above mentioned supports a hypothetical view that mesenchymal cells might be transformed into lymphocytic cells by stimulation of epithelial cells $\mathrm{s}^{22}$ and that epithelial cells might be transformed into lymphocytic cells by stimulation of mesenchymal cells (induction theory) ${ }^{8}$.

At the stage of lymph follicle maturation (15th day of incubation of the Coturnix embryo) the infrequent presence of clusters of epithelial cells in the outer zone indicates that the possibility that they are sometimes dissociated from the epithelial bud at earlier stages and that contribute to the formation of the reticulum of the outer zone of the lymph follicle. The cellular reticulum of the inner zone is composed solely of epithelial reticular cells and not contributed to by mesenchymal cells. There are some uncertainties in the thymus whether the thymic reticulum is composed solely of epithelial reticular cells or combined with mesenchymal reticulum, although recent electron microscopic findings showed ${ }^{9,15,21}$ that the mesenchymal cells were far less numerous than 
epithelial ones and that they could not be assumed to be the essential part of the thymic parenchyma. In this connection it is shown that the cellular reticulum of the inner zone of the bursal follicle is invariably of epithelial nature characterized by the presence of desmosomes and tonofilaments and the absence of intercellular collagen fibrils. This morphological situation may be intimately associated with the absence of invasion of blood vessels into the bud or the inner zone; a fundamentally different situation from that of thymus, although Takagi has recently described that cells which were recognized as mesenchymal were observed in the inner (or medullary) zone with the appearance of phagocytic cells at later stages after birth. ${ }^{38}$

\section{Characteristic features of lymphocytic cells of the bursal follicle}

The author observed that the bursal lymphoid cells at hatching stage largely measure 6-10 microns in cytoplasmic diameter in the inner zone and 4-8 microns in the outer zone. It contrasts with the data of 4-5 microns in the thymus.27,36 The smaller size of lymphocytes of the outer zone indicates that they either are a) carried from the inner zone and become mature earlier, derived $b$ ) from the unknown other sites or $c$ ) from undifferentiated mesenchymal cells in situ (i.e. in tunica propria of the bursa). Cytoplasm of bursal lymphocytic cells is filled with free ribosomes, isolated or aggregated (polysomes), explaining stronger basophilia than in the thymocytes. Sherman et al..$^{36}$ made an analysis of critical size of the lymphocytic cell populations of the developing chick bursa of Fabricius and thymus and concluded that characteristic shifts in cell size distribution, modal cell volume, and mean cell volume, occurred during morphogenesis of these organs. Their data showed that the cell size (modal peak) was 8 microns in the bursa and 5 microns in the thymus at 19th day of incubation; there were clear differences between the lymphocytic cells of these two structures. But they also showed that a progressive reduction in cell size occurred in both organs at 14th to 17 th day in the thymus and from 18th day of incubation to 6 -week-old in the bursa. On the other hand the mean cell size of the bursa was constantly larger than that of the thymus at least till 6 week old. My data at hatching stages agree with theirs. At the stages where the development of the bursal follicle has been completed, my finding indicates that there are essentially differences between lymphocytic cells of the thymus and of the bursa. In this connection it is interesting to correlate the morphologic findings with the concept of a dissociation of immune responses that the bursa controls the development of cells of the plasmacytic series which are concerned in immune reactions mediated by humoral antibody and that the thymus is primarily concerned with the development of cells of the lymphocytic series which mediate a direct cellular response 
to antigenic challenge. ${ }^{40}$ The relationship of bursal cells with plasmacytic series remains to be determined. Pyronine-positive lymphocytic cells in the bursal follicles may be erroneously taken as plasma cells by light microscopists, but they are clearly demonstrated as ribosome-rich and endoplasmic-reticulum-poor lymphocytic cells with electron microscope. No evidence of transition from bursal lymphocytic cells to plasmacytic series is obtained.

Previous electron microscopic observations ${ }^{29}$ indicate that there are two types of eosinophilic granulocytes in respect to specific granules. One possesses oval- or round-shaped (true eosinophil), another spindle-shaped specific granules (pseudoeosinophils). The author observed no spindle-shaped granules in the eosinophilic granulocytes in the bursa. On the other hand Osako did not mention the vacuoles and the transitional forms from granules to vacuoles. It is possible that these vacuolar structures are artefact products due to fixation as often seen in the specific granules of mast cells. The nature of the granules and the significance of granulocytopoiesis in the bursa remains to be settled.

\section{SUMMARY}

The development of lymph follicles of the bursa of Fabricius of chick and quail embryos was studied by light and electron microscopes. The epithelial cells of the inner (or medullary) zone were transformed both into reticular and lymphocytic series. There was a stage where a close contact between epithelial and mesenchymal cells through the disruption of the epithelial basement membrane of the primordial lymph follicle (bud). It was most plausible that cells of lymphocytic series not only in the outer but also in the inner zone are of dual origin: epithelial and mesenchymal. The inner (or medullary) zone of the bursal follicle consisted of epithelial cell reticulum and lymphocytic series without the contribution of mesenchymay cells and blood vessels. The outer (or cortical) zone consisted of mesenchymal cell reticulum and lymphocytic series with the partial contribution of epithelial cells and blood vessels. Lymphocytic cells of the bursa showed several developmental stages from blastic types to mediumsized lymphocytes. But they tended to have larger cytoplasmic diameters with stronger basophilia and more abundant free ribosomes in their cytoplasm than those of the thymus.

\section{ACKNOWLEDGEMENT}

The author wishes to acknowledge the continuous advice and criticism of Professor T. Kobayashi and Assistant Professor Y. Watanabe, the invaluable 
cooperation of Dr. N. Tamaoki throughout the present investigation, the supply of materials of Drs. T. Oda and M. Ichimura of Kamogawa, Chiba and of Dr. T. Asahara of the Kitasato Institute and the technical assistance of electron microscopy of Mr. Y. Yokota.

\section{REFERENCES}

1. Ackerman, G. A. and Knouff, R. A.: Lymphocytopoiesis in the bursa of Fabricius. Amer. J. Anat. 104; 163-208, 1959.

2. Ackerman, G. A. and Knouff, R. A.: Testosterone suppression of mesenchymal alkaline phosphatase activity and lympho-epithelial nodule formation in the bursa of Fabricius in the embryonic chick. Anat. Reco. 146: 23-27, 1963.

3. Ackerman, G. A.: Electron microscopy of the bursa of Fabricius of the embryonic chick with particular reference to the lymphoepithelial nodules. J. Cell Biol. 13: 127-146, 1962.

4. Aramaki, T. and Tamaoki, N.: Morphologic study of lymphatic tissues (XII). Electron microscope observations of the human and mouse neoplasms of the thymus. Sixth International Congress for Electron Microscopy, Kyoto, 1966.

5. Archer, O. K., Sutherland, D. E. R., and Good, R. A.: Appendix of the rabbit: a homologue of the bursa in the chicken? Nature 200:337-379, 1963.

6. Aspinall, R. L., Meyer, R. K., and Rao, M. A.: Effect of various steroids on the development of the bursa Fabricii in chick embryos. Endocrinol. 68: 944-949, 1961.

7. Aspinall, R. L., Meyer, R. K., Graetzer, M. A., and Wolfe, H. R.: Effect of thymectomy on the survival of skin homografts in chickens. J. Immun. 96: 872-877, 1963.

8. Auerbach, R.: Experimental analysis of the origin of cell types in the development of the mouse thymus. Develop. Biol. 9: 336-354 1961.

9. Clark, S. L. Jr.: The thymus in mice of strain $127 / \mathrm{J}$, studied with the electron microscope. Amer. J. Anat. 112: 1-9, 1963.

10. Cooper, M. D. and Peterson, R. D. A.: Delineation of the thymic and bursal lymphoid systems in the chicken. Nature 205: 143-146, 1965.

11. Cooper, M. D., Peterson, R. D. A., South, M. A., and Good, R. A.: The functions of the thymus system and bursa system in the chicken. J. Exp. Med. 123: 75$102,1966$.

12. Cooper, M. D., Schwartz, M. L., and Good, R. A.: Restoration of gamma globulin production in agammaglobulinemia chickens. Science 151: 471-473, 1966.

13. Fawcett, D. W.: Intercellular bridges. Expt. Cell Res. Suppl. 8: 174-187, 1961.

14. Graetzer, M. A., Wolfe, H. R., Aspinall, R. L., and Meyer, R. K.: Effect of thymectomy and bursectomy on precipitin and natural hemagglutinin production in the chicken. J. Immun. 90: 878-887, 1963.

15. Hoshino, T.: Electron microscopie study of the epithelial reticular cells of the thymus. Z. Zellforsch. 59: 513-529, 1963.

16. Ichimura, M.: Embryonic development and histochemical study of the bursa of Fabricius in the embryo of the chickens (in Japanese). J. Keio Med. Soc. 44: 571582, 1967

17. Tzard, J.: Présence de desmosomes entre des cellules épithéliales et des celluies lymphocytaires dans le thymus de cobaye. J. Micros. 5: 361-364, 1966.

18. Jaffe, W. P. and Fecheimer, N. S.: Cell transport and the bursa of Fabricius. Nature 212: 92, 1966. 
19. Jankovic, B. D. and Leskowitz, S.: Restoration of antibody producing capacity in bursectomized chickens by bursal gratts in millipore chambers. Yroc. Soc. Exp. Biol. Med. 118: 1164-1166 1965.

20. Jolly, J.: La bourse de Fabricius et les organes lymphoépithéliaux. Arch. Anat. Microscop. 16: 363-547, 1915.

21. Kameya (Aramaki), T. and Watanabe, Y.: Electron microscopic observations on human thymus and thymoma. Acta Path. Jap. 15 (2) : 223-246, 1965.

22. Kobayashi, '1': On the so-called central lymphoid organs. Symposium on structure and function of the thymus. 'The 17th General Assembly of the Japan Medical Congress, Nagoya, 1967.

23. Luft, J. L.: Improvements in epoxy resin embedding methods. J. Biophys. Biochem. Cytol. 9: 409-414, 1961.

24. Meyer, R. K., Rao, M. A., and Aspinall, R. L.: Inhibition of the development of the bursa of Fabricius in the embryos of the common fowl by 19-nortestosterone. Endocrinol. 64:890-897, 1959.

25. Moore, M. A. S. and Owen, J. J. T.: Experimental studies on the development of the bursa of Fabricius. Develop. Biol. 14: 40-51, 1966.

26. Mueller, A. P., Wolfe, H. R., and Meyer, R. K.: Precipitin production in chickens. XXI. Antibody production in bursectomized chickens and in chickens injected with 19-nortestosterone on the fifth day of incubation. J. Immun. 172-179, 1960.

27. Murray, R. G., Murray, A., and Pizzo, A.: The fine structure of the thymocytes of young rats. Anat. Reco. 151: 17-40, 1965.

28. Okuyama, T. and Imamura, M.: Histogenesis of thymic tumor induced by polyoma virus. The General Meeting of the Japanese Pathological Society, April 1967.

29. Osako, R.: An electron microscopic observations on the specific granules of eosinophil leukocytes of Vertebrates. Acta Haem. Jap. 22: 134, 1959.

30. Peterson, R. D. A., Burmester, B. R., Frederichson, T. N., Purchase, H. G., and Good, R. A.: Effect of bursectomy and thymectomy on the development of visceral lymphomatosis in the chicken. J. Nat. Cancer Inst. 32: 1343-1354 1964.

31. Rao, M. A., Aspinall, R. L., and Meyer, R. K.: Effect of dose and time of administration of 19-nortestosterone on the differentiation of lymphoid tissue in the bursa Fabricii of chick embryos. Endocrinol. 70: 159-166 1962.

32. Reynolds, E. S.: The use of lead citrate at high $\mathrm{pH}$ as an electronopaque stain in electron microscopy. J. Cell Biol. 17: 208, 1963.

33. Sato, T.: A modified method for lead staining of thin sections. Twenty-third Scientific Meeting of the Japanese Society of Electron Microscopy, Fukuoka, Japan, 1967.

34. St. Pierre, R. L., and Ackerman, G. A.: Influence of bursa implantation upon lymphocytic nodules and plasma cells in spleens of bursectomized chickens. Proc. Soc. Exp. Biol. Med. 122: 1280-1284, 1966.

35. St. Pierre, R. L. and Ackerman, G. A.: Bursa of Fabricius in chicken; Possible humoral factor. Science 147: 1307-1308, 1965.

36. Sherman, J. and Auerbach, R.: Quantitative characterizations of chick thymus and bursa development. Blood 27: 371-379, 1966.

37. Szenberg, A. and Warner, N. L.: Dissociation immunological responsiveness in fowls with a hormonally arrested development of lymphoid tissue. Nature 194: 146-147 1962.

38. Takagi, T.: Ultrastructure of the bursa of Fabricius in the chick. Symposium of Japan Society for Cell Biology IX: Immunocytology, Symposia Cell. Chem. 18: 205-222, 1967. Kyoto, 1966.

39. Warner, N. L. and Szenberg, A.: Immunological reactivity of burseless chickens 
in graft versus host reactions. Nature 199: 43-44 1963.

40. Warner, N. L. and Szenberg, A.: The immunological functions of the bursa $\mathbf{c f}$ Fabricius in the chicken. Ann. Rev. Microbiol. 18: 253-268, 1964.

41. Warner, N. L.: Gamma-globulin synthesis in hormonally bursectomized chickens. Nature 203: 198-199 1964.

42. Woods, R. and Linna, J.: The transport of cells from the bursa of Fabricius to the spleen and the thymus. Acta Path. Microbiol. Scandinav. 64: 470-476, 1965.

43. Yamaguchi, Y. et al.: The role of thymus and bursa of Fabricius in the development of lymphoid tissue and immunologic capacity. Jap. J. Bact. 19: 447-457, 1964.

\section{EXPLANATION OF FIGURES}

Specimens of Figs. 4, 6, 7, 8, 9, 10, 11, and 14 were fixed with Zenker's formalin and stained with hematoxylin-eosin except those of Figs. 11 and 14 which were impregnated with silver. The specimen of Fig. 5 was fixed with 1 per cent osmium tetroxide, embedded in Epon and stained with alkaline methylene blue. Those of Figs. 12 and 13 were fixed with Carnoy's solution and stained with methylgreenpyronine. The scale of each figure indicates $1 \mu$ except where otherwise noted.

Fig. 1. Number of free ribosomes per 0.25 micron squares of 8 cells in the epithelial bud shown in Fig. 28. In each cell the number of free ribosomes in 10 randomly selected 0.25 micron squares were counted and the averages taken (see also the explanation of Figs. 27 and 28).

Fig. 2. Width of mitochonodria of 8 cells in the epithelial bud shown in Fig. 28. Widths of ten mitochondria in 8 selected cells were measured and the averages taken (see also explanation Figs. 27 and 28).

Fig. 3. A schematic diagram of the origin, differentiation and migration of the cells of the lymph follicles during the deveopment of the bursa of Fabricius in the chick and the Coturnix. Modified from Ackerman's original figure (see reference 1). The thick arrows are concluded by the author's findings. The thin ones are concluded and assumed from the other previous investigation.

Figs. 4 and 5. A bursal epithelial bud of 13th day of incubation of a chick. Arrows of Fig. 5 indicate distinct basophilic lymphoblastic cells. Granulocytes are seen in the tunica propria.

Fig. 6. Bursal developing lymph follicle of 15 th day of incubation of a chick embryo.

Fig. 7. Bursal developing lymph follicles of 16 th day of incubation of a chick embryo.

Fig. 8. Bursal lymph follicles of 18th day of incubation of a chick embryo.

Fig. 9. Almost accomplished bursal lymph follicles of 20 th day of incubation of a chick embryo.

Fig. 10. A portion of a thymus of the same chick embryo as shown in Fig. 8. The same magnification as in Fig. 8. Compare the lymphocytic cell size between the two organs.

Fig. 11. Bursal follicles of 18th day of incubation of a chick embryo. Silver impregnation. Note a distinct demonstration of the inner and outer zones whose epithelial cell monolayer surrounds the inner zone.

Fig. 12. A bursal lymph follicle of 18th day of incubation of a chick embryo. Methylgreen-pyronine staining reveals strongly pyronine-positive cytoplasm of lymphocytic cells both in the inner and outer zones.

Fig. 13. A portion of a thymus of the same chick embryo as in Fig. 10. Methylgreen- 
pyronine staining. Note the small cell size of thymocytes and rarity of pyronine-positive cells.

Fig. 14. Two bursal lymph follicles of 70-day-old chick. Silver impregnation clearly demonstrates demarkation of both zones. Note the difference of distribution of "silver fibers" between both zones. In the outer zone a silver-impregnated fibers form a reticulum.

Fig. 15. 15th day of incubation of a Coturnix embryo. Cytoplasm of one lymphocytic cells of the inner zone is shown. Numerous ribosomes, seen as isolated and aggregated (polyribosomes), are observed. Magnification, x62,500.

Fig. 16. Part of Fig. 28. An undifferentiated epithelial cell (UEp, cell of No. 19 of Figs. 27 and 28), a lymphoblastic cell (LB, No. 24 of Fig. 27) and a mesenchymal cell (M, No. 25 of Fig. 27). Mitochondria of the epithelial cell are rather small, tonofilaments are well developed here. Large mitochondria and free ribosomes of the lymphoblastic cell in the tunica propria are shown. Disruption of the basement membrane (BM) is evident and a close contact of the epithelial cell (UEp) with the mesenchymal cell (M) is cleary demonstrated (arrow). Magnification, x12,500.

Fig. 17. Part of Fig. 28. Large mitochondria and moderate number of free ribosomes are seen in the cytoplasm of one lymphocytic cell (L) (No. 15 of Fig. 27). Tonofilaments are observed as a bundle in the cytoplasmic processes of one epithelial cell (To). Magnification, x25,000.

Fig. 18. The rectangular area indicated in Fig. 29 is magnified here. The disruption of the basement membrane (BM) and the passage of a group of undifferentiated epithelial cells connected by desmosomes (D) through the disrupted membrane are observed. Cytoplasmic processes of the epithelial cells are highly interdigitated. Magnification, x12,500.

Fig. 19. 15th day of incubation of a chick embryo. A medium-sized lymphocyte (L) surrounded by undifferentiated epithelial cells (UEp) and closely associated with a mesenchymal cell (M) by breaking the basement membrane is shown. Magnification, $\mathrm{x} 11,300$.

Fig. 20. 15th day of incubation of a chick embryo. Close contacts of epithelial cells (Ep) with the tunica propria and mesenchymal cells (M) (arrows) are clearly shown. There are two points of the disruption of the basement membrane (BM). The epithelial cells are connected each other with desmosomes (D). A moderately developed Golgi body and medium-sized mitochondria are seen. Free ribosomes are sparcely scattered. Rough elements of endoplasmic reticulum are poorly developed. Magnification $\mathrm{x11,300.}$

Fig. 21. 15th day of incubation of a Coturnix embryo. The epithelial reticular cells (ER) form a network by their cytoplasmic processes connecting each other with desmosomes (D). The desmosomes shown here is short in length and has fine tonofilaments converging upon both cytoplasmic membranes. The cytoplasm of the epithelial reticular cells have small amount of ribosomes and scant rough-surfaced endoplasmic reticulum. On the right side the border between the inner and outer zones is demonstrated. A continuous line of the basement membrane (BM) and small dense plaques (P) are seen at the border of the epithelial reticular cell. Two endothelial cells (Ed) of a blood capillary are shown to be intimately associated with the basal area of the inner zone. A large lymphocytic cell $(\mathrm{L})$ is filled with free ribosomes, often seen as polyribosomes (see also Fig. 15).

Fig. 22. A portion of a granulocyte of the 15th day of incubation of a chick embryo. The granulocyte, observed as eosinophilic and peroxydase-negative by light 
microscopy, possesses a dozen of dense homogeneous spherical granules $(G)$, measuring from 100 to 800 milimicrons in diameter at one side of the nucleus. A small number of vacuoles containing dense coarse irregularly-shaped grains (V) are also seen. Transistional forms ( $T$ ) between the two are sometimes encountered. Single lead staining. Note a marked difference of densities of the granules according to staining procedures (see next Fig.). Magnification, $\mathrm{x} 12,500$.

Fig. 23. A portion of a granulocyte of the 18th day of incubation of a chick embryo. Double staining. Magnification, $\mathrm{x} 12,500$.

Fig. 24. 15th day of incubation of a Coturnix embryo. The left half corresponds to the outer and the right one to the inner zone. The basement membrane (BM) delimiting the two zones is disrupted at the arrows, where one lymphocytic cell is passing either from the inner to the outer zone or vice virsa. Free ribosomes in the cytoplasm of the lymphocyte are far more concentrated in the left half or in the outer zone than in the right in the inner zone. Areas of the left side to the basement membrane are devoid of epithelial reticular cells (ER).

Fig. 25. 15th day of incubation of a Coturnix embryo. Two typical lymphocytic cells and processes of epithelial reticular cells in the inner zone of bursal lymph follicle. Condensation of nuclear chromatin and abundant free ribosomes, often seen as polyribosomes. Magnification, x25,000.

Fig. 26. 15th day of incubation of a Coturnix embryo. The left half is the inner zone and the right half is the outer zone. The basal epithelial reticular cells (ER) line the border of the two zones. The epithelial reticular cells are characterized by the presence of desmosomes (D) and tonofilaments. Dense plaques (P) are also seen at the margin of the basal epithelial cell. A continuous basement membrane (BM) is running from the top to the bottom of the figure. On the upper right in the outer zone two epithelial reticular cells which are connected by a desmosome is observed. L, Lymphocytic cell. Magnification, $\mathrm{x} 15,000$.

Figs. 27 and 28. These are an electron micrograph (Fig. 28) and its traced figure (Fig. 27) of a bursal epithelial bud of 13th day of incubation of a chick embryo. Each cell of the bud and its surroundings is numbered in the traced figure. The cells of the bud border are Nos. $6,8,9,14,15.19,22$, $31,32.34$, etc. The basement membrane is shown bv a dotted line. Surface epithelial cells, $1,2,3,5,33,35,40,41,42,43,46,47,48$ and 49 . Distinet undifferentiated epithelial cells, $9,11,13,19,20,22,29$ and 34 . Distinct lymphoblastic cells. $4,7,10,16,23,24,26,38$ and 39 . Intermediate forms between epithelial cells and lvmphoblasts, 15,18 and 31 . Mesenchymal and fibroblastic cells, 25, 27 and 37. The arrows indicate the disruptions of the basement membrane. Lu, lumen of the surface of the epithelium.

Fig. 29. This is a traced figure of an electron micrograph of a developing lymph follicle of the 15th day of incubation of a chick embryo. Distinct lymphocytic cells of moderate size (L) are increased in number both in the bud and the subjacent tunica propria. The disruptions of the basement membrane (BM) in the polar region (arrows) are obvious and the protrusion of undifferentiated epithelial cells as a group through the crevices of the membrane into the tunica propria is observed, which is demonstrated in more details in Fig. 18, which shows the area of a rectangle indicated.

Firs. 30 and 31. These are an electron micrograph (Fig. 31) and its traced figure (Fig. 30) of the 15th day of incubation of the Coturnix embryo. 
The inner (lower portion) and outer (upper portion) zones are well separated by an almost completely continuous basement membrane (indicated by a dotted line and BM), the disruption of which is indicated by two arrows. The inner zone is filled with numerous large and medium-sized lymphocytes. The reticular network formed by thin cytoplasmic processes of epithelial cells characterized by the presence of desmosomes and tonofilament is indicated by blackened areas in the traced figure. BM, basement membrane BV, blood vessel $\mathrm{F}$, fibroblastic cell $\mathrm{M}$, mesenchymal cell $\mathrm{Mi}$, mitotic figure. Lymphocytic series are not indicated by letters. Magnification, x3,000. 


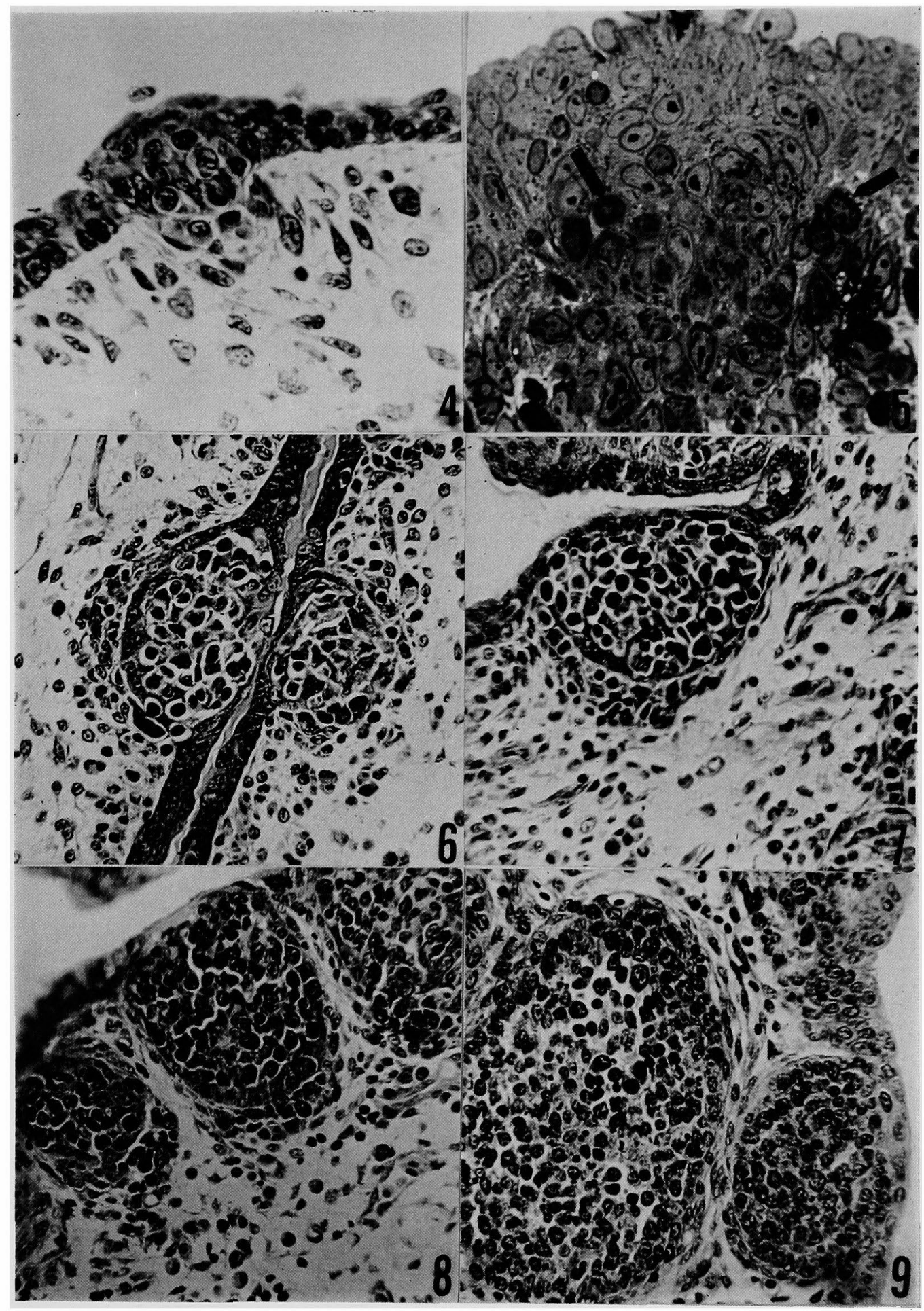




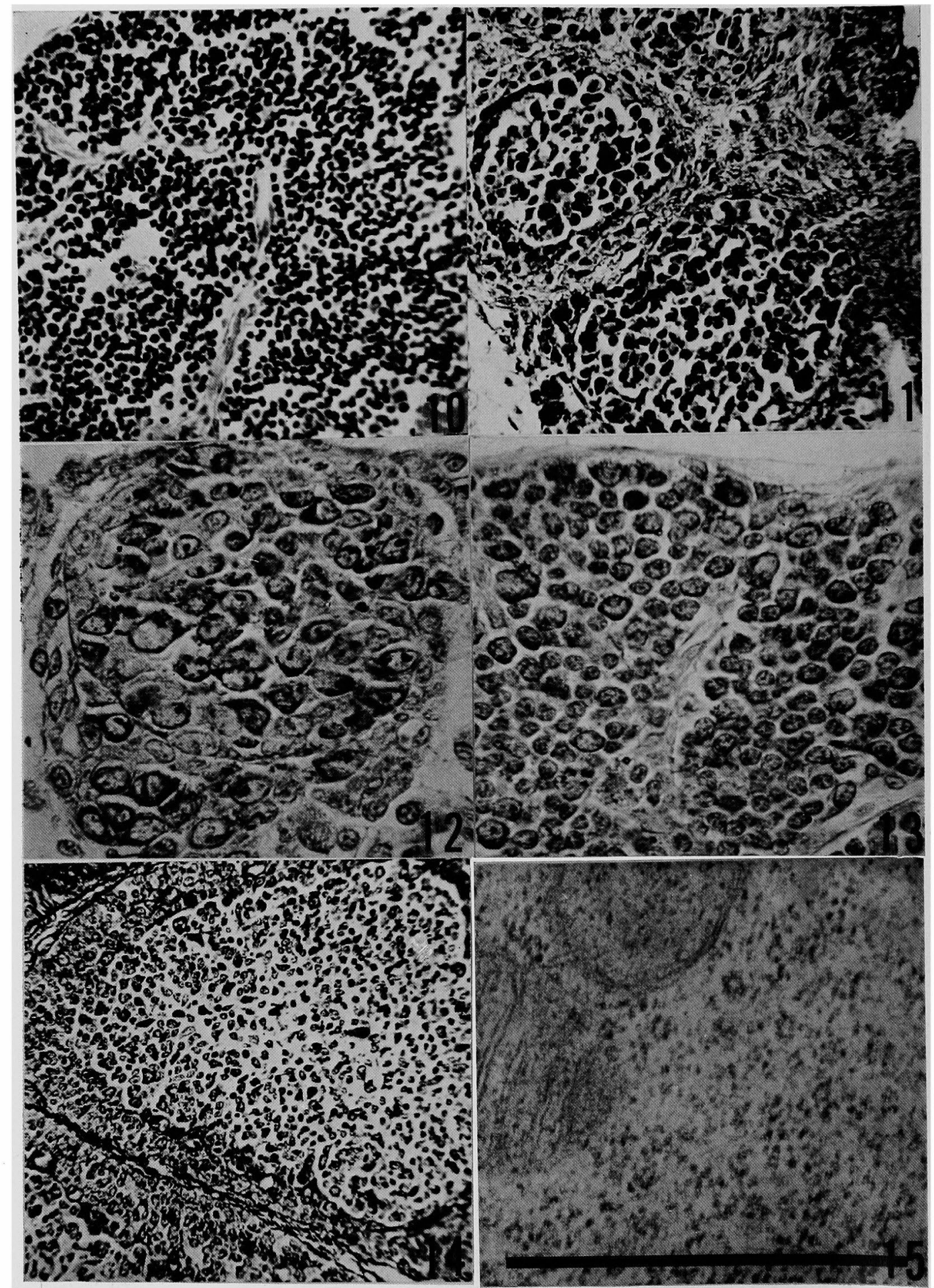

T. ARAMAKI 


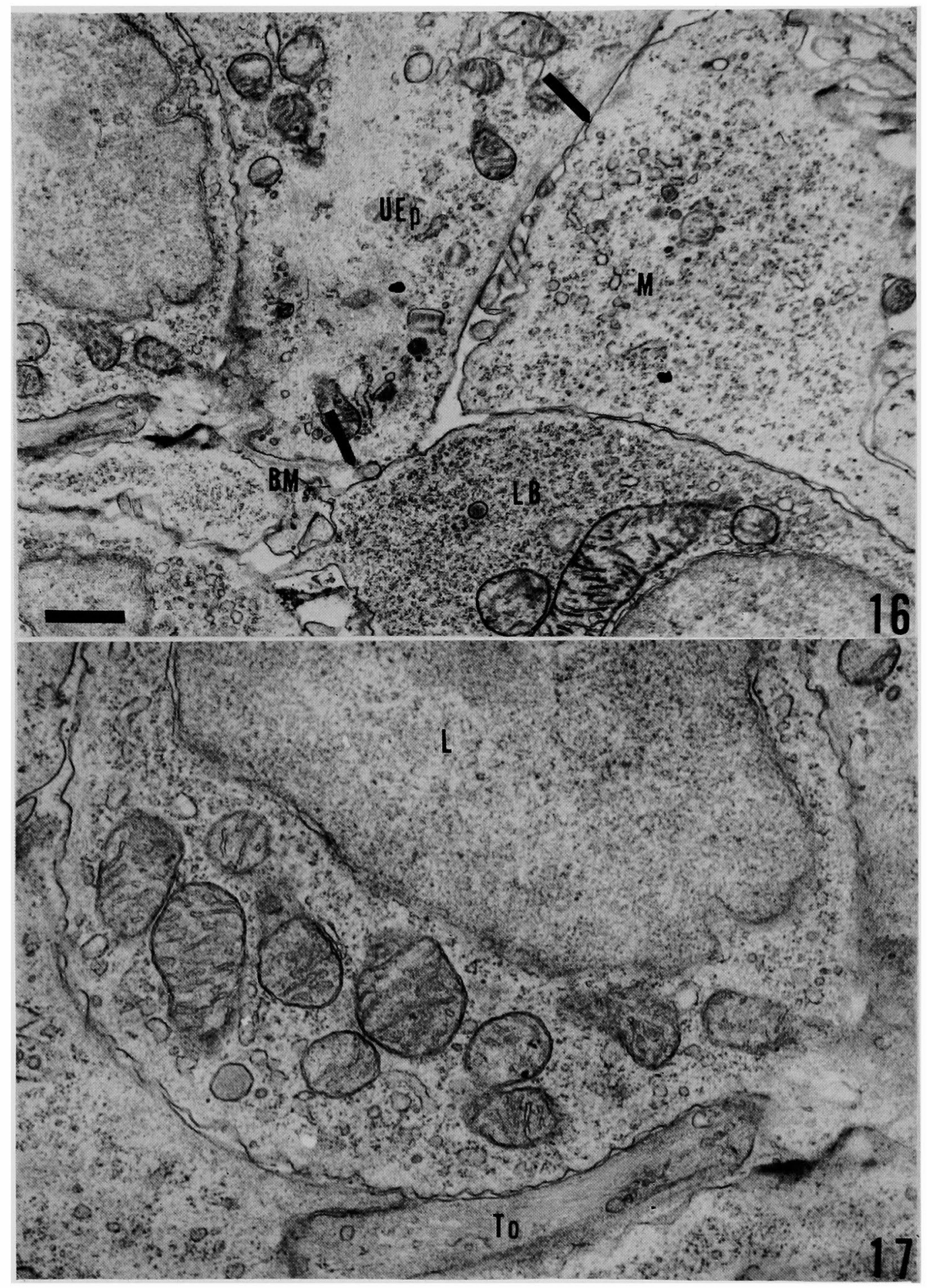




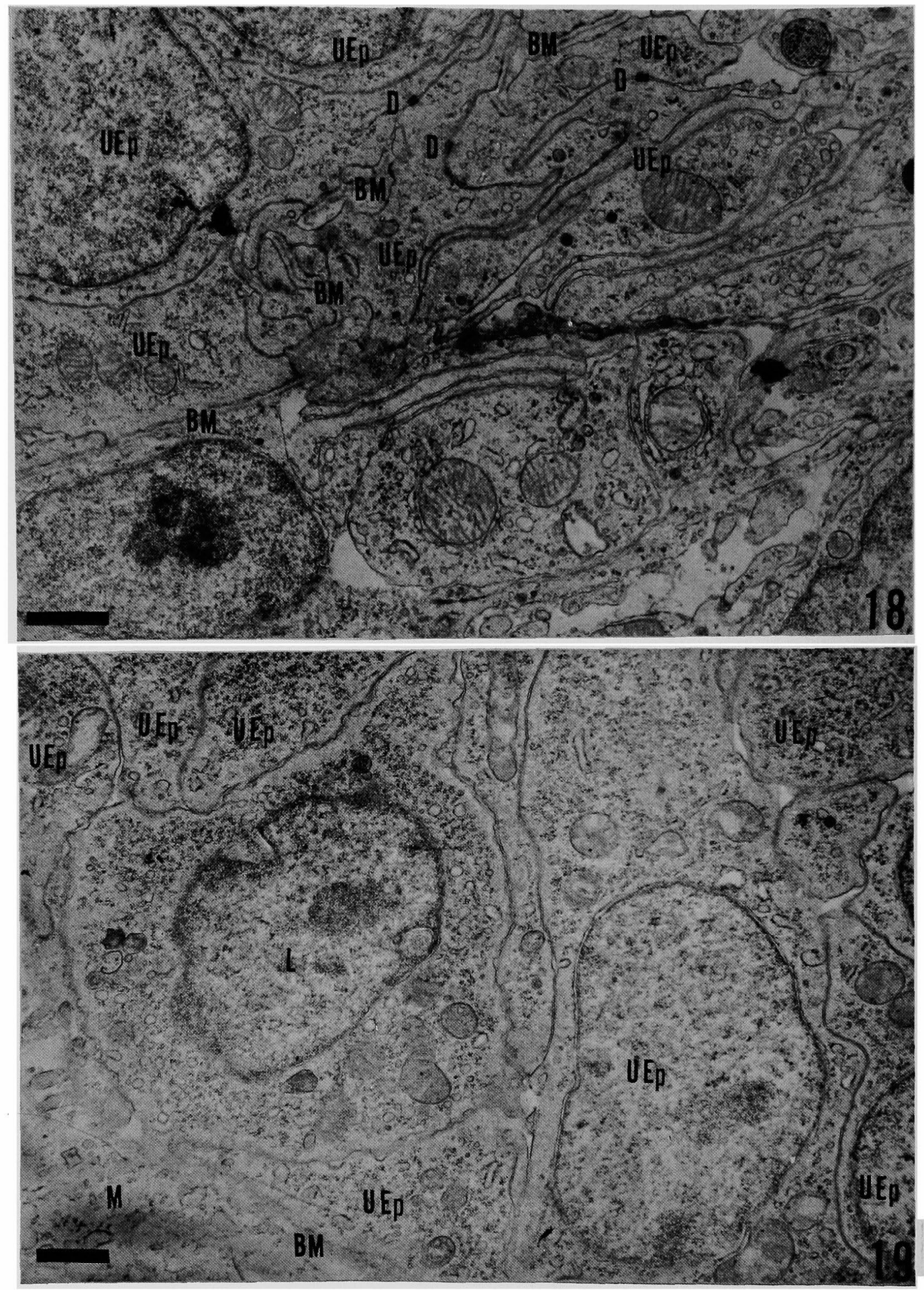

\section{T. ARAMAKI}



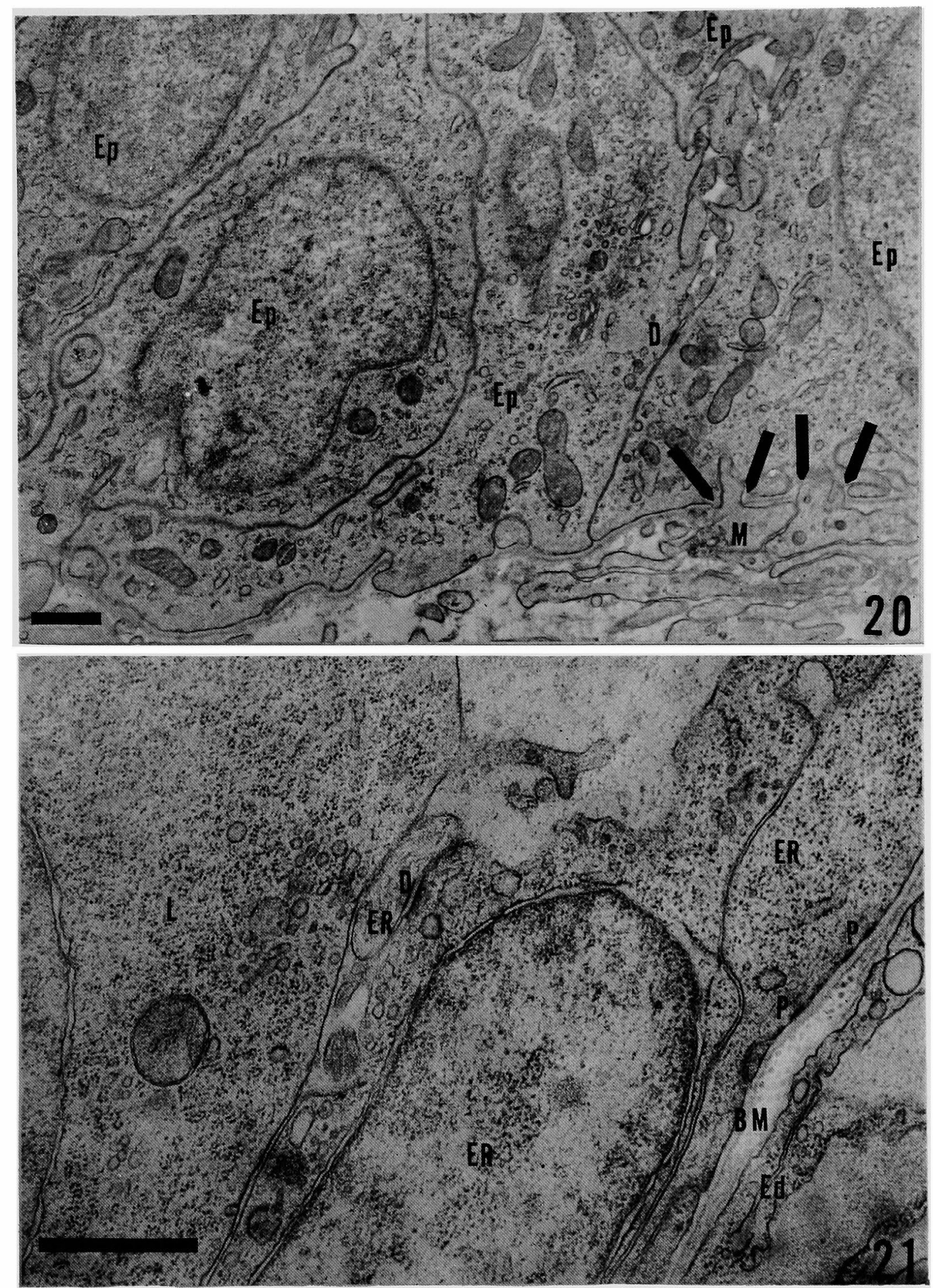


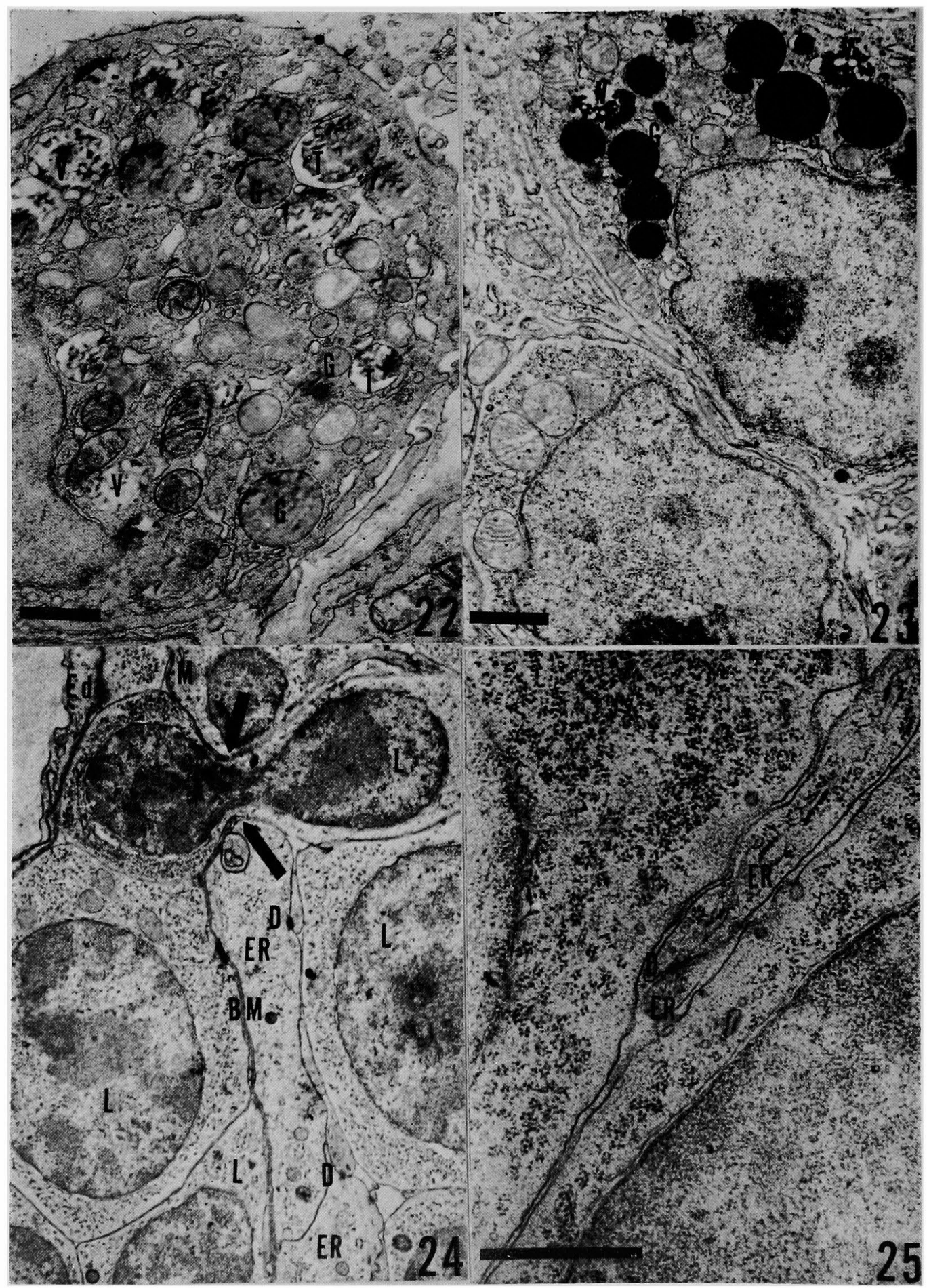

T. ARAMAKI 

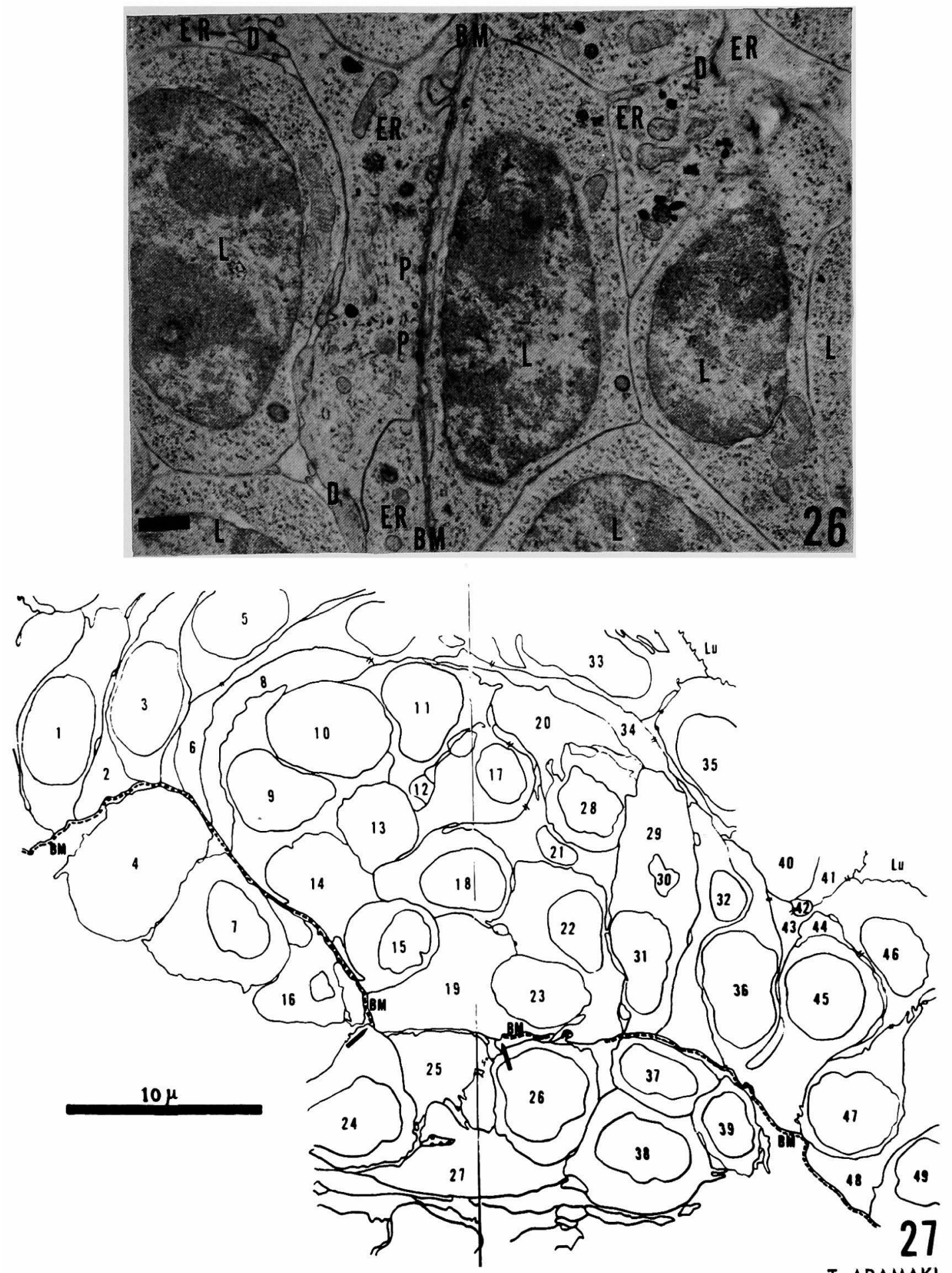

T. ARAMAKI 


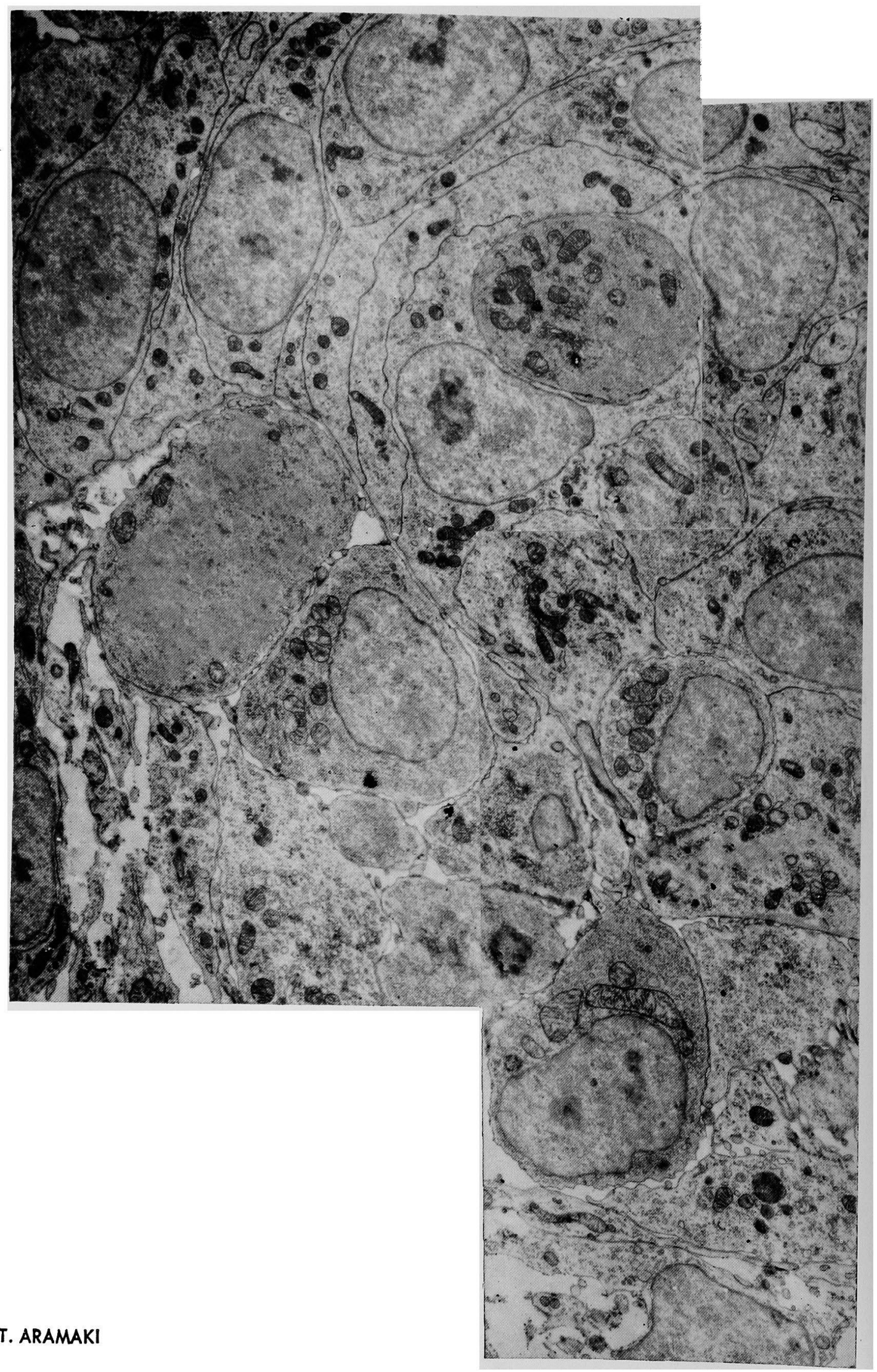




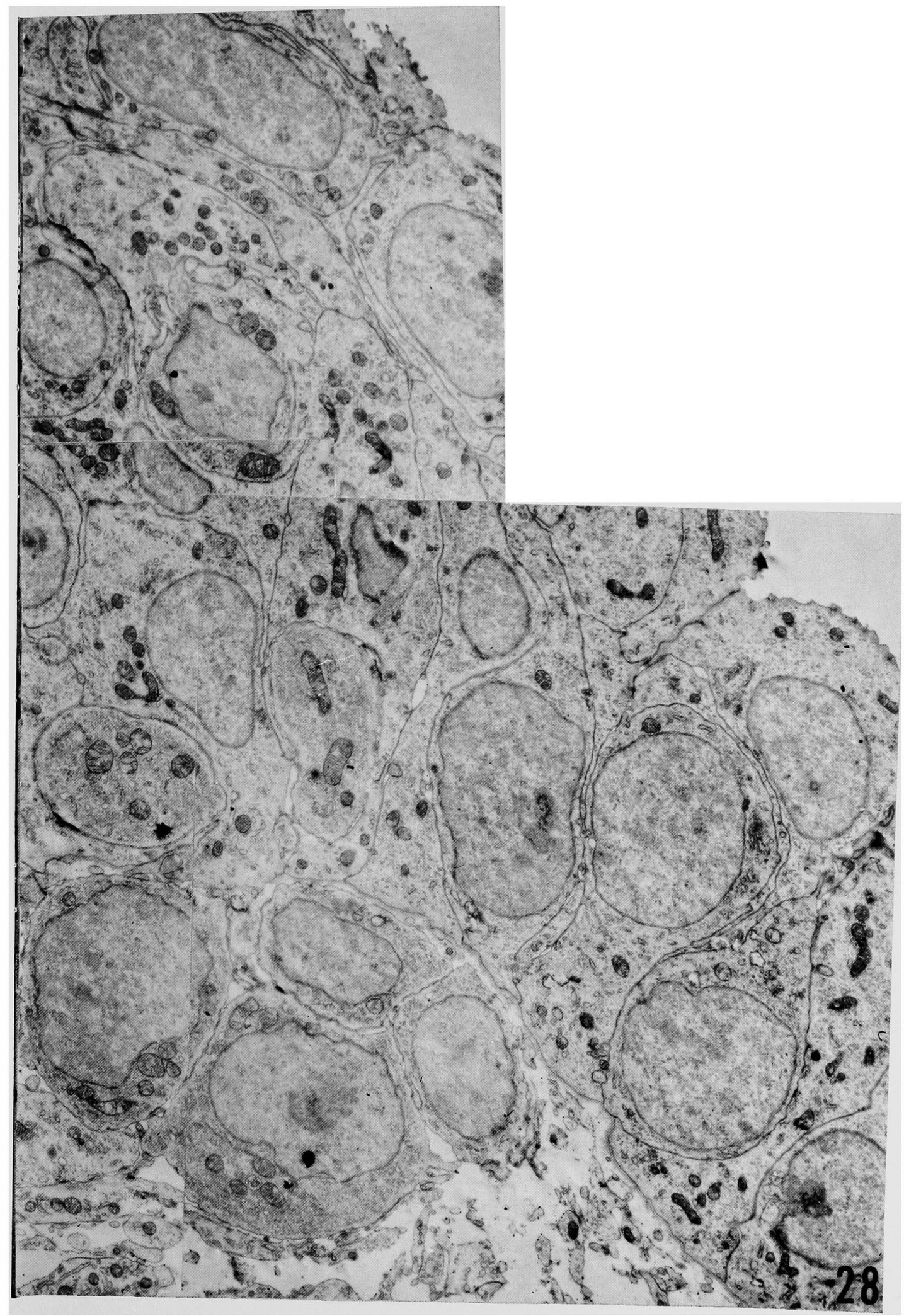




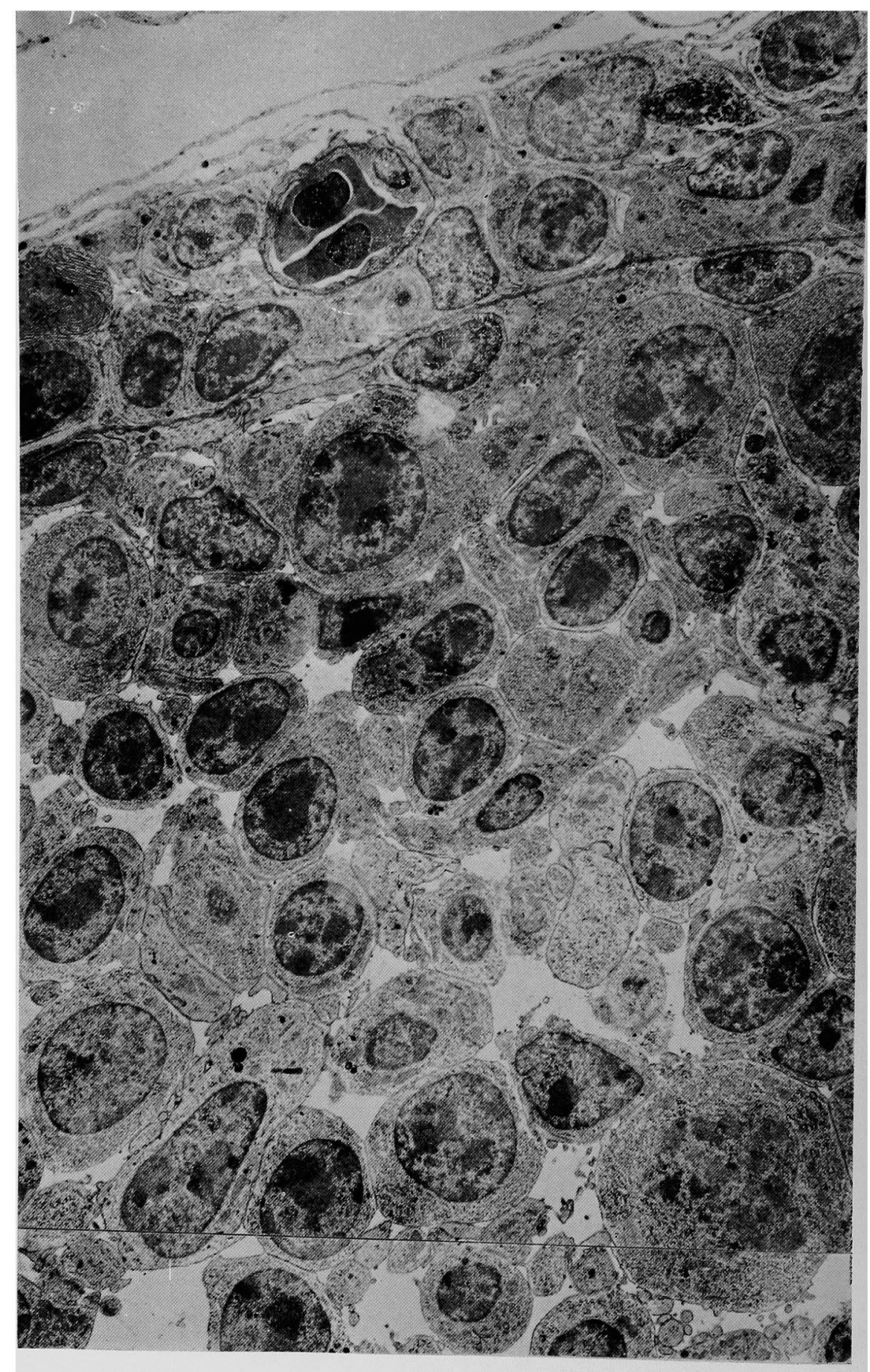






T. ARAMAKI 


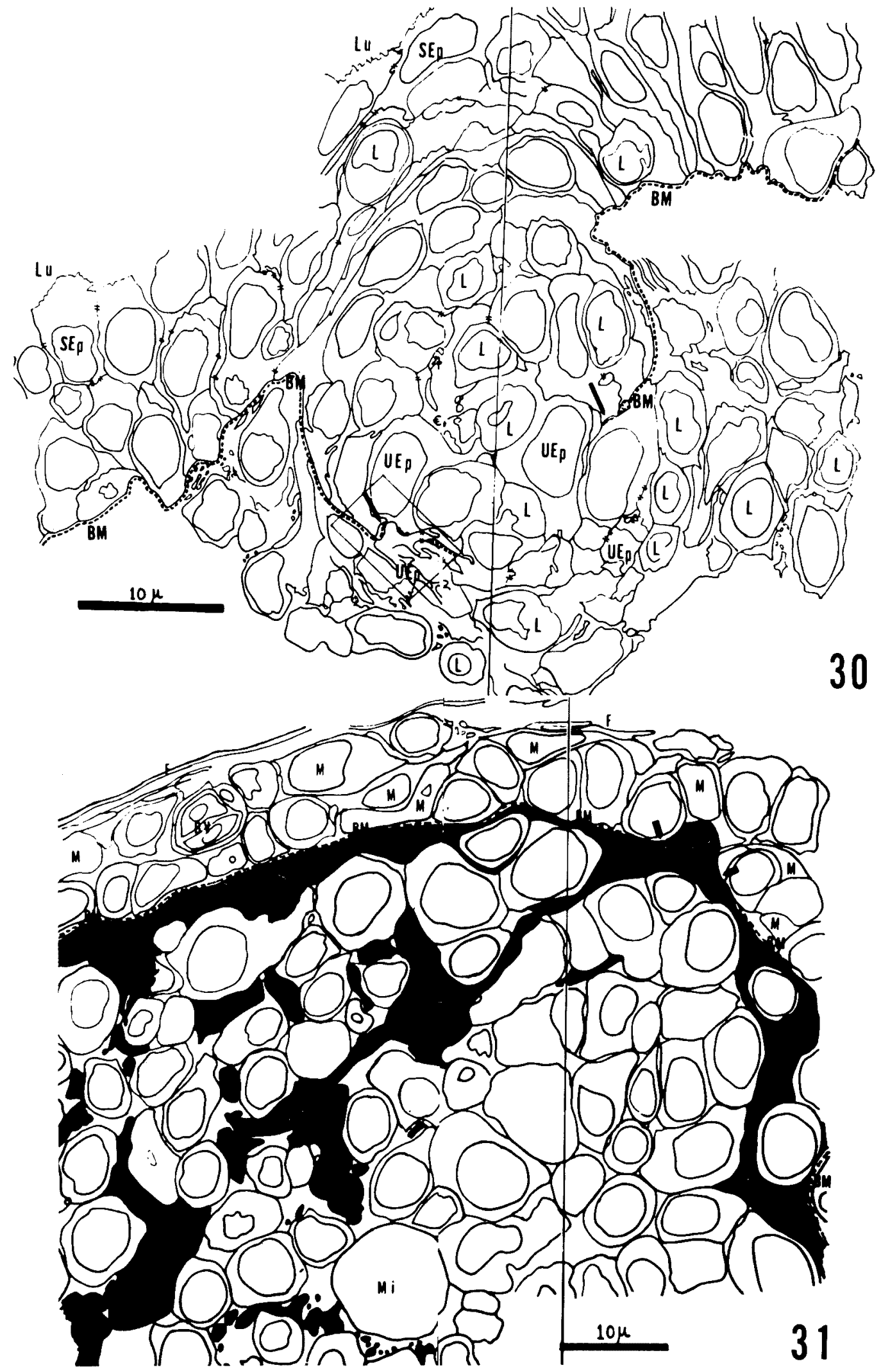

T. ARAMAKI 